\title{
PENGARUH PEMANASAN OHMIC TERHADAP KADAR ANTOSIANIN KULIT BUAH NAGA MERAH (HYLOCEREUS POLYRHIZUS)
}

\section{(The Effect of Ohmic Warming on the Skin Anthocyanin Level of Red Dragon Fruit (Hylocereus polyrhizus))}

\author{
Wahyuni $\mathbf{M}^{1 *}$, Salengke ${ }^{2)}$, dan Mursalim ${ }^{3)}$ \\ ${ }^{1)}$ Program Studi Teknik Pertanian, Universitas Hasanuddin, Makassar \\ ${ }^{2}$ Program Studi Teknik Pertanian, Universitas Hasanuddin, Makassar \\ ${ }^{3}$ Program Studi Teknik Pertanian, Universitas Hasanuddin, Makassar \\ *) Email korespondensi: uniwahyuni13@gmail.com
}

\begin{abstract}
ABSTRAK
Warna merupakan salah satu sifat organoleptik yang penting bagi makanan mempengaruhi persepsi konsumen. Zat pewarna alami yang berpotensi untuk diekstrak adalah antosianin dari kulit buah naga. Antosianin adalah pigmen yang sifatnya polar dan larut dengan baik dalam pelarut-pelarut polar. Oleh sebab itu, dalam penelitian ini dilakukan ekstraksi antosianin dengan pelarut air. Pemanasan Ohmic merupakan salah satu teknologi alternatif yang dapat digunakan pada proses ekstraksi pada suhu tinggi. Ohmic merupakan proses pemanasan, dimana arus listrik dilewatkan melalui bahan pangan. Penelitian ini bertujuan untuk mempelajari karakteristik pemanasan Ohmic dan konduktivitas listrik bubur (puree) kulit buah naga, dan mengetahui perubahan kadar antosianin dalam kulit buah naga setelah pemanasan ohmic. Proses pemanasan dilakukan pada tiga suhu yaitu $70{ }^{\circ} \mathrm{C}, 90{ }^{\circ} \mathrm{C}, 110{ }^{\circ} \mathrm{C}$. Hasil yang diperoleh memperlihatkan bahwa laju pemanasan dan perubahan konduktifitas listrik relatif konstan sampai mencapai suhu setting point. Kadar antosianin pada kulit buah naga sangat dipengaruhi oleh suhu dan lama pemanasan, dimana semakin tinggi suhu pemanasan dan waktu pemanasan semakin lama maka semakin rendah antosianin dalam produk yang dihasilkan.
\end{abstract}

Kata Kunci: Ohmic, Ekstraksi, Kulit Buah Naga, Antosianin, Konduktivitas Listrik

\section{PENDAHULUAN}

\section{Latar Belakang}

Penentuan mutu bahan pangan pada umumnya sangat tergantung pada beberapa faktor seperti cita rasa, tekstur, nilai gizi, dan juga sifat mikrobiologis. Sebelum faktor lain dipertimbangkan, secara visual faktor warna tampil lebih dahulu dan sangat menentukan kesukaan konsumen.

Di Indonesia, terdapat kecenderungan penyalahgunaan pemakaian zat pewarna untuk berbagai bahan pangan, misalnya zat warna untuk tekstil dan kulit digunakan untuk mewarnai bahan makanan. Hal ini sangat berbahaya bagi kesehatan karena adanya residu logam berat pada zat pewarna tersebut (Winarti, et al., 2010). Pewarna sintetik lebih disukai karena lebih ekonomis, praktis dan sifat pewarnaannya yang lebih stabil dan seragam. Tetapi kelemahan yang dimiliki oleh pewarna sintetik diantaranya adalah sifatnya yang karsinogenik dan beracun (Hidayah, 2013).

Adanya batasan-batasan pada penggunaan beberapa macam zat warna sintetik mengakibatkan pentingnya penelitian terhadap zat warna alami (Mastuti, et al., 2013). Berkembangnya industri pengolahan pangan dan terbatasnya jumlah serta kualitas zat pewarna alami menyebabkan pemakaian zat warna sintetik meningkat (Winarti, et al., 2008). Oleh 
sebab itu, perlu ditingkatkan pencarian alternatif sumber zat pewarna alami. Zat pewarna alami yang berpotensi untuk diekstrak diantaranya adalah antosianin (Hanum, 2000).

Buah-buahan merupakan bahan pangan yang kaya akan antioksidan. Salah satu tanaman buah yang saat ini sedang populer di masyarakat adalah buah naga. Kulit buah naga berpotensi sebagai sumber pewarna makanan karena mempunyai pigmen warna merah, yang dapat memberikan warna yang menarik pada makanan. Antosianin adalah pigmen yang dapat berfungsi menurunkan kadar kolesterol dalam darah.

Antosianin telah memenuhi persyaratan sebagai pewarna makanan alami, karena tidak menimbulkan kerusakan pada bahan makanan maupun kemasannya serta bukan merupakan zat yang beracun bagi tubuh sehingga secara internasional telah diijinkan sebagai zat pewarna makanan (Astawan dan Kasih, 2008). Antosianin termasuk ke dalam senyawa fenolik dan flavonoid yaitu pigmen alami yang menyebabkan warna merah, oranye, ungu, dan biru yang berlimpah dalam bunga dan buah-buahan. Antosianin memiliki banyak manfaat kesehatan, termasuk peningkatan ketajaman penglihatan, aktifitas anti kanker, antioksidan, dan pemeliharaan permeabilitas normalvascular (Hidayah, 2013).

Teknologi ohmic merupakan salah satu teknologi pengolahan pangan yang dapat diterapkan dalam industri pangan. Teknologi ohmic itu sendiri merupakan suatu proses pemanasan, dimana arus listrik (khususnya arus bolak-balik AC) dilewatkan melalui bahan pangan. Dengan pengolahan ohmic, proses pengolahan konsumsi energi yang dihasilkan dapat diturunkan dan dapat meningkatkan efisiensi proses pengolahan secara keseluruhan dan meningkatkan kualitas produk yang dihasilkan (Arifah, 2016).

Berdasarkan latar belakang diatas penelitian ini bertujuan untuk mengetahui karakteristik pemanasan ohmic dan perubahan konduktivitas listrik selama pemanasan ohmic, serta kadar antosianin dalam zat warna alami dari kulit buah naga.

\section{Tujuan dan Kegunaan}

Penelitian ini bertujuan untuk mengetahui konduktivitas listrik, karakteristik pemanasan ohmic dan kadar antosianin bubur kulit buah naga setelah proses pasteurisasi secara ohmic.

Kegunaan dari penelitian ini adalah memanfaatkan limbah kulit buah naga menjadi sesuatu yang bernilai serta sebagai bahan informasi dalam pengembangan teknologi Ohmic untuk pengolahan kulit buah naga.

\section{METODE PENELITIAN}

\section{Alat}

Alat yang digunakan pada penelitian ini adalah reaktor ohmic, colorymeter, $\mathrm{pH}$ Horiba, viskometer, refraktometer, sentrifuge, pisau, gelas piala, botol sampel, saringan, timbangan, corong, blender, kertas saring, pengaduk, dan spektrofotometer UVVIS.

\section{Bahan}

Bahan yang digunakan pada penelitian ini adalah buah naga merah, air, kertas label.

\section{Prosedur Penelitian}

1. Persiapan Bahan Sampel

a. Menyiapkan kulit buah naga (membersihkan, memotong).

b. Menghaluskan kulit buah naga menggunakan blender.

c. Menyaring buah naga yang telah dihaluskan.

2. Proses pemanasan dengan ohmic

a. Menyiapkan sampel yang telah disaring.

b. Menyiapkan alat pemanas ohmic.

c. Menyalakan reaktor ohmic.

d. Memasukkan bahan pada alat pemanasan, lalu mengatur suhu yang akan digunakan.

e. Mengatur suhu reaktor ohmic $\left(70^{\circ} \mathrm{C}\right.$ ,90 $\left.{ }^{\circ} \mathrm{C}, 110{ }^{\circ} \mathrm{C}\right)$.

f. Menyambungkan laptop dengan data Logger. 
g. Mengambil data suhu, arus, dan Voltase yang telah terekam didata Logger.

3. Proses pengukuran absorbansi

a. Menyiapkan sampel.

b. Menyiapkan pelarut air.

c. 100 gr sampel ditambahkan pelarut (1:2 = bahan : pelarut $)$.

d. Mengekstraksi sampel secara maserasi selama 1 jam.

e. Menyaring sampel menggunakan kertas saring.

f. Memasukkan sampel kedalam alat disentrifugasi selama 5 menit.

g. Menyiapkan alat spektrofotometer UV-VIS.

h. Mengukur absorbansinya pada panjang gelombang optimum.

i. Menghitung kadar antosianin menggunakan rumus.

\section{Parameter Pengamatan Penelitian}

\section{Konduktivitas listrik}

Konduktivitas listrik yang dihasilkan selama proses pemanasan dipengaruhi oleh kuat medan listrik dan kandungan ion didalamnya. Persamaan yang digunakan adalah:

Dimana:

$$
\sigma=\frac{I}{V} \frac{L}{A}
$$

$\sigma:$ Konduktivitas listrik

I : Besarnya arus listrik (Ohm)

$\mathrm{V}:$ Tegangan (Volt)

$\mathrm{L}$ : Jarak unit (m)

A : Luas penampang

Pengukuran Warna $(\mathbf{L}, \mathbf{a}, \mathbf{b})$

Pengukuran warna $(\mathrm{L}, \mathrm{a}, \mathrm{b})$ dilakukan dengan menggunakan colorimeter, cara pengukurannya adalah dengan cara mengkalibrasi alat kemudian mendekatkan alat colorimeter kesampel dan secara otomatis nilai L,a,b akan muncul pada display alat.

\section{Kadar Antosianin}

Kandungan total antosianin atau Total Anthocyanin Concentration (TAC) dalam $\mathrm{mg} / \mathrm{L}$ pada sample dihitung dengan rumus:
Dimana:

A : Absorbansi

MW : Berat Molekul Antosianin $=449,2$ g/gmol

DF : Faktor Pelarutan

$\varepsilon \quad$ : Etinction Coefficient $=26.900 \mathrm{~L} / \mathrm{cm} . \mathrm{mol}$

b $\quad$ : Diameter Kuvet $=1$

\section{Pengukuran pH}

Pengukuran $\mathrm{pH}$ dilakukan dengan menggunakan $\mathrm{pH}$ Horiba, cara pengukurannya adalah mengkalibrasi alat dengan aquades, menyiapkan sampel sebanyak $2 \mathrm{ml}$ gr kemudian meneteskannya ke alat $\mathrm{pH}$ Horiba lalu mencatat nilai $\mathrm{pH}$ yang ditampilkan alat.

\section{Total Padatan Terlarut}

Total padatan terlarut diukur dengan menggunakan Refraktometer, cara pengukurannya adalah mengkalibrasi alat terlebih dahulu dengan aquades, sebanyak 5 $\mathrm{ml}$ gr sampel diteteskan ke refraktometer lalu mencatat nilai total padatan terlarut yang ditampilkan alat.

\section{Viskositas}

Pengukuran Viskositas dilakukan dengan menggunakan viscometer, cara pengukurannya adalah mengkalibrasi alat dengan mengatur nivo pada posisi seimbang, memilih rotor yang sesuai dengan jenis sampel setelah itu sebanyak $200 \mathrm{ml}$ gr sampel diukur dengan kecepatan Rpm 60.

\section{HASIL DAN PEMBAHASAN}

\section{Pengaruh Suhu Terhadap Laju \\ Pemanasan}

Bahan pangan yang dilewati arus listrik memberi respon berupa pembangkitan panas secara internal akibat adanya tahanan listrik dalam bahan pangan tersebut. Jumlah panas yang dibangkitkan dalam bahan pangan akibat aliran arus berhubungan langsung dengan kerapatan arus yang ditimbulkan oleh besarnya medan listrik (field strength) dan konduktifitas listrik dari bahan pangan yang diolah (Sastry dan Paniappan, 2001).

$$
T A C=\frac{A \times M W \times D F \times 100}{\varepsilon \times b}
$$




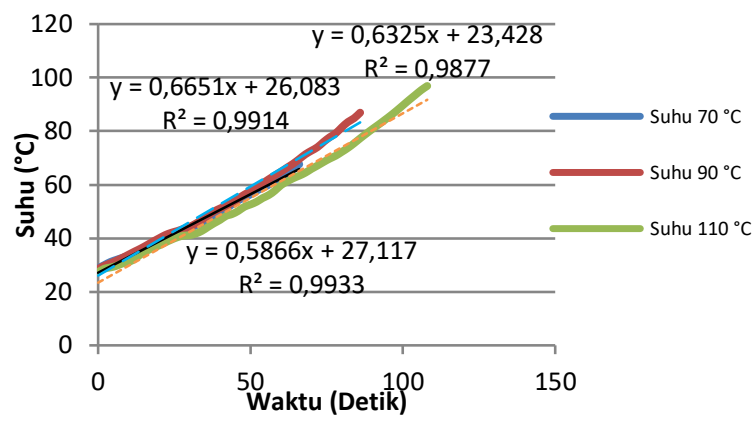

Gambar 1. Grafik pengaruh suhu terhadap laju pemanasan dengan waktu 30 menit

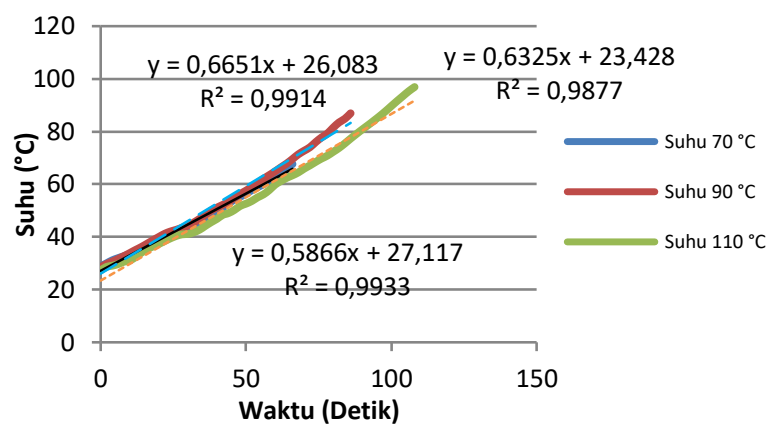

Gambar 2. Grafik pengaruh suhu terhadap laju pemanasan dengan waktu 45 menit

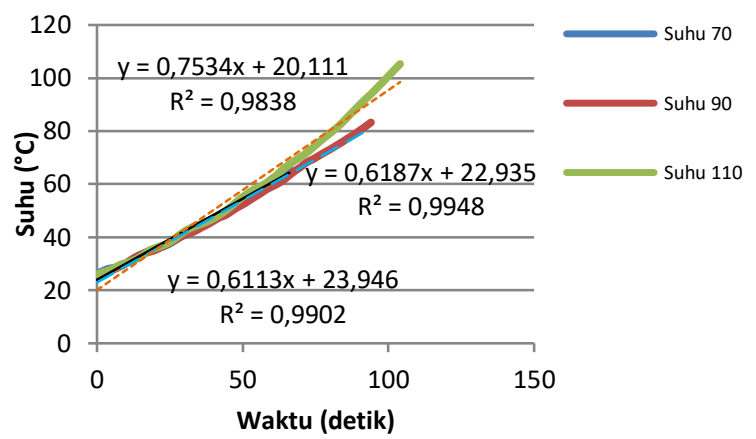

Gambar 3. Grafik pengaruh suhu terhadap laju pemanasan dengan waktu 60 menit

Pada penelitian yang telah dilakukan pada gambar 1,2 dan 3 menunjukkan laju pemanasan pada suhu $70{ }^{\circ} \mathrm{C}, 90{ }^{\circ} \mathrm{C}$ dan 110 ${ }^{\circ} \mathrm{C}$ stabil dan konstan hingga mencapai suhu setting point untuk suhu $70{ }^{\circ} \mathrm{C}$ rata-rata waktu yang dibutuhkan adalah 78 detik. Pada suhu $90{ }^{\circ} \mathrm{C}$ rata-rata waktu yang dibutuhkan untuk mencapai suhu setting point adalah 92 detik. Sedangkan untuk suhu $110{ }^{\circ} \mathrm{C}$ rata-rata waktu yang dibutuhkan adalah 111 detik. Laju peningkatan suhu linear terhadap waktu, semakin tinggi suhu yang digunakan maka semakin lama waktu yang dibutuhkan untuk mencapai suhu setting point.
Jurnal AgriTechno. Vol. 11 (2): 139-146

https://doi.org/ 10.20956/at.v11i2.135

\section{Konduktivitas Listrik}

Konduktivitas listrik meningkat dengan kenaikan suhu, pemanasan ohmic menjadi lebih efektif sebagai suhu meningkat, yang secara teoritis dapat mengakibatkan pemanasan berlangsung cepat. Konduktivitas listrik dipengaruhi oleh kandungan ion, untuk menyesuaikan konduktivitas listrik produk (kedua fase) dengan meningkatkan ion (misalnya garam) untuk mencapai efektif pemanasan ohmic (Ruan et al., 2001).

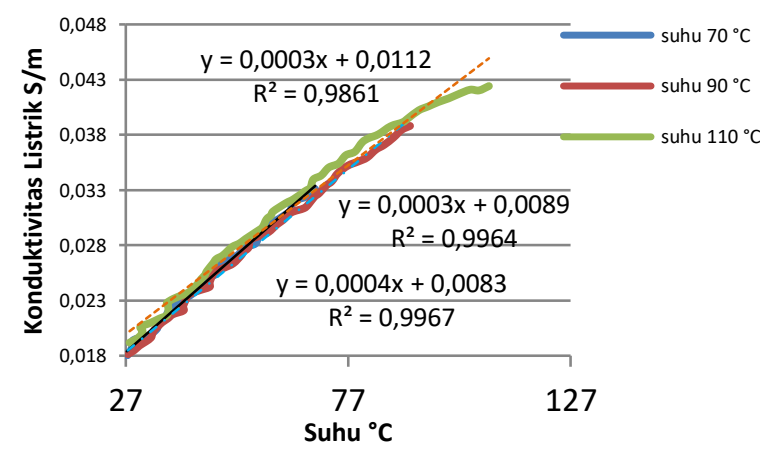

Gambar 4. Grafik Konduktivitas Listrik $(\mathrm{S} / \mathrm{m})$

Pada gambar 4 menunjukkan hubungan konduktivitas listrik dengan suhu. Dimana pemanasan dimulai dengan suhu ruang nilai konduktivitas listriknya adalah 0.018 dan nilai konduktivitas listrik pada saat suhu mencapai suhu pemanasan $70{ }^{\circ} \mathrm{C}$ nilai konduktivitas listriknya adalah 0.033 , konduktivitas listrik pada saat suhu mencapai suhu pemanasan $90{ }^{\circ} \mathrm{C}$ nilai konduktivitas listriknya adalah 0.038 , dan untuk suhu pemanasan $110{ }^{\circ} \mathrm{C}$ nilai konduktivitas listrik yang didapatkan pada saat suhu mencapai suhu setting point adalah 0.042 . Hal ini sesuai dengan penelitian yang telah dilakukan (Sastry dan Barach, 2002) konduktifitas listrik bahan pangan meningkat secara linear dengan peningkatan suhu sehingga proses pemanasan menjadi semakin efektif dengan semakin meningkatnya suhu selama proses pemanasan ohmic berlangsung.

\section{Kadar Antosianin}

Pada penelitian ini bubur kulit buah naga yang telah melalui proses pasteurisasi secara ohmic dengan rentan waktu dan suhu 
tertentu yang kemudian di ekstraksi selama 1 jam. Untuk nilai antosianin dapat dilihat pada gambar grafik berikut:

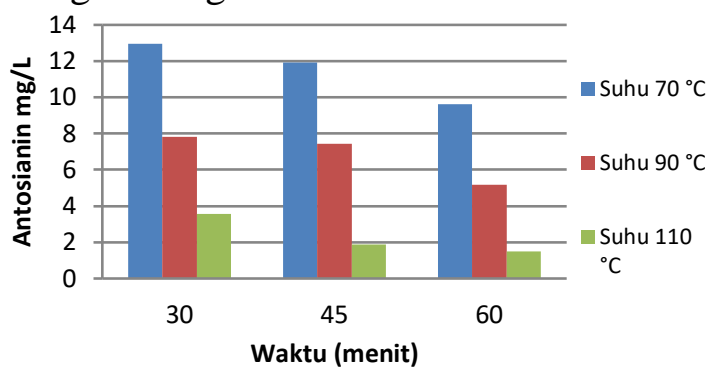

Gambar 5. Grafik Kadar Antosianin mg/L

Pada penelitian ini dipatkan nilai kadar antosianin untuk suhu $70^{\circ} \mathrm{C}$ waktu 30 menit adalah $12.9 \mathrm{mg} / \mathrm{L}$, suhu $70{ }^{\circ} \mathrm{C}$ waktu 45 menit adalah $11.90 \mathrm{mg} / \mathrm{L}$, suhu $70{ }^{\circ} \mathrm{C}$ waktu 60 menit adalah $9.61 \mathrm{mg} / \mathrm{L}$. Suhu $90{ }^{\circ} \mathrm{C}$ waktu 30 menit adalah 7.83, suhu $90{ }^{\circ} \mathrm{C}$ waktu 45 menit adalah $7.45 \mathrm{mg} / \mathrm{L}$, suhu 90 ${ }^{\circ} \mathrm{C}$ waktu 60 menit adalah $5.17 \mathrm{mg} / \mathrm{L}$. Suhu $110{ }^{\circ} \mathrm{C}$ waktu 30 menit adalah $3.56 \mathrm{mg} / \mathrm{L}$, suhu $110{ }^{\circ} \mathrm{C}$ waktu 45 menit adalah 1.87 $\mathrm{mg} / \mathrm{L}$, dan untuk suhu $110{ }^{\circ} \mathrm{C}$ waktu 60 menit adalah $1.45 \mathrm{mg} / \mathrm{L}$, dapat kita perhatikan bahawa semakin tinggi suhu dan semakin lama pemanasan maka semakin rendah kadar antosianinnya. Hal ini sesuai dengan pernyataan Ingarth, et al., (2015), yang menyatakan bahwa suhu sangat mempengaruhi antosianin dan penggunaan waktu yang terlalu lama perlu dihindari karena dapat meningkatkan degradasi senyawa antosanin.

\section{Total Padatan Terlarut \%Brix}

Pada penelitian ini dilakukan pengukuran total padatan terlarut dimana total padatan terlarut merupakan ukuran semua senyawa organik dan anorganik yang terlarut dalam suatu cairan, yang menunjukan perbandingan padatan yang berbeda. Nilai total padatan terlarut dapat dilihat pada grafik berikut:

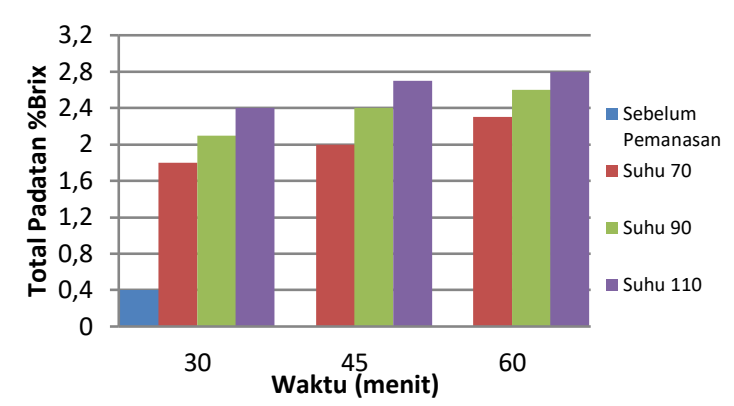

Gambar 6. Grafik Total padatan terlarut $\%$ Brix

Pada gambar dapat di lihat bahwa total padatan sebelum pemanasan nilainya adalah $0,4 \%$ Brix dan setelah pemanasan selama 30 menit suhu $70{ }^{\circ} \mathrm{C}$ nilainya adalah $1,8 \%$ Brix, suhu $70{ }^{\circ} \mathrm{C}$ waktu 45 menit nilai total padatannya adalah $2 \%$ Brix, suhu $70{ }^{\circ} \mathrm{C}$ waktu 60 menit total padatannya adalah 2,3 $\%$ Brix, suhu $90^{\circ} \mathrm{C}$ waktu 30 menit nilai total padatannya adalah $2,1 \%$ Brix, suhu $90{ }^{\circ} \mathrm{C}$ waktu 45 menit nilai total padatannya adalah 2,4\%Brix, suhu $90{ }^{\circ} \mathrm{C}$ waktu 60 menit total padatannya adalah $2,6 \%$ Brix, suhu $110{ }^{\circ} \mathrm{C}$ waktu 30 menit nilai total padatannya adalah $2,4 \%$ Brix, untuk suhu pemanasan $110{ }^{\circ} \mathrm{C}$ waktu 45 menit nilai total padatannya adalah $2,7 \%$ Brix, suhu $110^{\circ} \mathrm{C}$ waktu 60 menit nilai total padatannya adalah $2,8 \%$ Brix. Ini menunjukan bahwa semakin tinggi suhu yang digunakan dan semakin lama waktu pemanasan maka total padatan pada sampel juga meningkat.

\section{Grafik Nilai pH}

Nilai $\mathrm{pH}$ pada bubur kulit buah naga dapat dilihat pada grafik berikut:

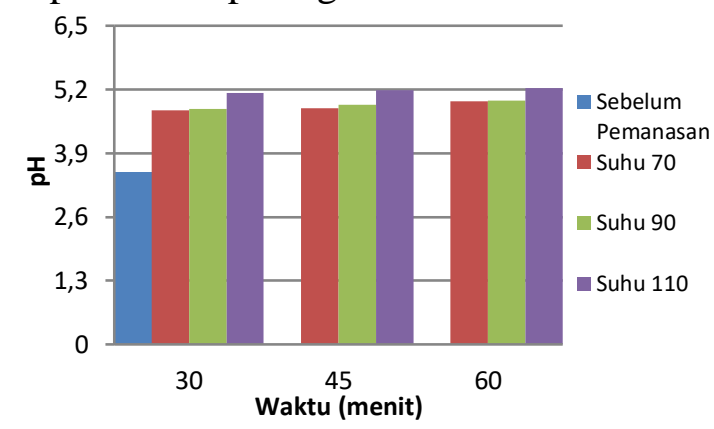

Gambar 7. Grafik Nilai $\mathrm{pH}$

Pengamatan $\mathrm{pH}$ dapat dilihat pada gambar 7 bahwa terjadi pengkatan $\mathrm{pH}$ seiring dengan meningkatnya suhu dan lama pemanasan nilai $\mathrm{pH}$ pada suhu pemanasan 
$70{ }^{\circ} \mathrm{C}$ waktu 30 menit adalah 4.78 , suhu 70 ${ }^{\circ} \mathrm{C}$ waktu45 menit adalah 4.82 , suhu $70{ }^{\circ} \mathrm{C}$ waktu 60 menit adalah 4.96, suhu $90{ }^{\circ} \mathrm{C}$ waktu 30 menit adalah 4.80 , suhu $90{ }^{\circ} \mathrm{C}$ waktu 45 menit adalah 4.89 , suhu $90{ }^{\circ} \mathrm{C}$ waktu 60 menit adalah 4.98, suhu $110{ }^{\circ} \mathrm{C}$ waktu 30 menit adalah 5.13 , suhu $110{ }^{\circ} \mathrm{C}$ waktu 45 menit adalah 5.18, suhu $110{ }^{\circ} \mathrm{C}$ waktu 60 menit adalah 5.23, semakin tinggi suhu dan semakin lama waktu pemanasan maka nilai pHnya meningkat.

\section{Grafik Nilai L, a, b}

Pada penelitian ini proses pemanasan kulit buah naga dilakukan dengan 3 perlakuan yang bervariasi yaitu pemanasan pada suhu $70^{\circ} \mathrm{C}$, suhu $90^{\circ} \mathrm{C}$, dan suhu 110 ${ }^{\circ} \mathrm{C}$ dalam setiap perlakuan masing-masing dilakukan 3 kali pengujian, hal ini dimaksudkan untuk melihat keseragaman warna pada satu suhu pemanasan menggunakan colorimeter sehingga diperoleh nilai $\mathrm{L}$, *a dan $* \mathrm{~b}$.

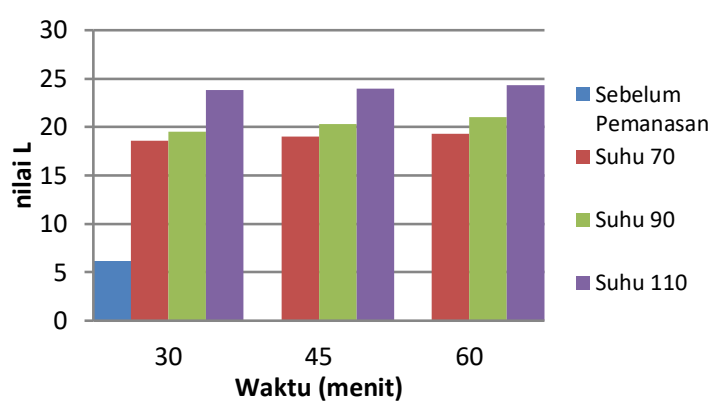

Gambar 8. Grafik Parameter Nilai L

Gambar 8 menunjukan pengaruh pemanasan ohmic terhadap nilai parameter $\mathrm{L}$ untuk suhu $70{ }^{\circ} \mathrm{C}$, suhu $90{ }^{\circ} \mathrm{C}$, dan suhu 110 ${ }^{\circ} \mathrm{C}$. Suhu $70{ }^{\circ} \mathrm{C}$ dengan waktu pemanasan 30 menit diperoleh nilai L 18.6, suhu $70{ }^{\circ} \mathrm{C}$ dengan waktu 45 menit diperoleh nilai L 19, suhu $70{ }^{\circ} \mathrm{C}$ dengan waktu 60 menit diperoleh nilai L 19.3, suhu $90{ }^{\circ} \mathrm{C}$ waktu 30 menit diperoleh nilai L 19.5 , suhu $90{ }^{\circ} \mathrm{C}$ waktu 45 menit diperoleh nilai L 20.3, suhu $90{ }^{\circ} \mathrm{C}$ waktu 60 menit diperoleh nilai L 21, suhu $110{ }^{\circ} \mathrm{C}$ waktu 30 menit diperoleh nilai $\mathrm{L}$ 23.8, suhu $110{ }^{\circ} \mathrm{C}$ waktu pemanasan 45 menit diperoleh nilai L 24, dan suhu $110^{\circ} \mathrm{C}$ waktu pemanasan 60 menit nilai L yang diperoleh adalah 24.3. Dari hasil pengamatan yang diperoleh dapat disimpulkan bahwa semakin tinggi suhu yang digunakan dan semakin lama waktu pemanasan maka nilai $\mathrm{L}$ yang didapat semakin tinggi.

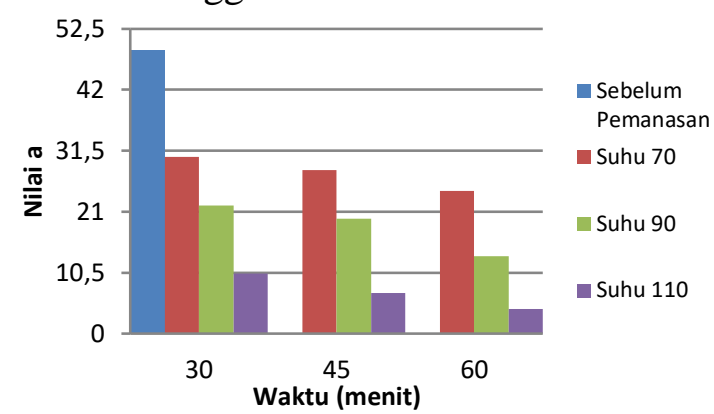

Gambar 9. Grafik Parameter Nilai *a

Gambar 9 menunjukan pengaruh pemanasan ohmic terhadap nilai parameter *a. pada penelitian ini diperoleh nilai *a untuk suhu $70{ }^{\circ} \mathrm{C}$, suhu $90{ }^{\circ} \mathrm{C}$, dan suhu 110 ${ }^{\circ} \mathrm{C}$. Suhu $70{ }^{\circ} \mathrm{C}$ dengan waktu pemanasan 30 menit diperoleh nilai *a 30.5 , suhu $70{ }^{\circ} \mathrm{C}$ dengan waktu 45 menit diperoleh nilai $*_{a}$ 28.2, suhu $70{ }^{\circ} \mathrm{C}$ dengan waktu 60 menit diperoleh nilai *a 24.6 , suhu $90{ }^{\circ} \mathrm{C}$ waktu 30 menit diperoleh nilai *a 22.1 , suhu $90{ }^{\circ} \mathrm{C}$ waktu 45 menit nilai $*$ a yang didapat adalah 19.8, suhu $90{ }^{\circ} \mathrm{C}$ waktu 60 menit diperoleh nilai *a 13.3 , suhu $110{ }^{\circ} \mathrm{C}$ dengan waktu pemanasan 30 menit diperoleh nilai *a 10.3, suhu $110{ }^{\circ} \mathrm{C}$ dengan waktu pemanasan 45 menit diperoleh nilai *a 7 , dan suhu $110{ }^{\circ} \mathrm{C}$ waktu pemanasan 60 menit nilai *a yang diperoleh adalah 4.2. Dari hasil pengamatan yang diperoleh dapat disimpulkan bahwa semakin tinggi suhu yang digunakan dan semakin lama waktu pemanasan maka nilai *a yang didapat semakin. Nilai $*_{a}$ mengindikasikan warna merah dan hijau.

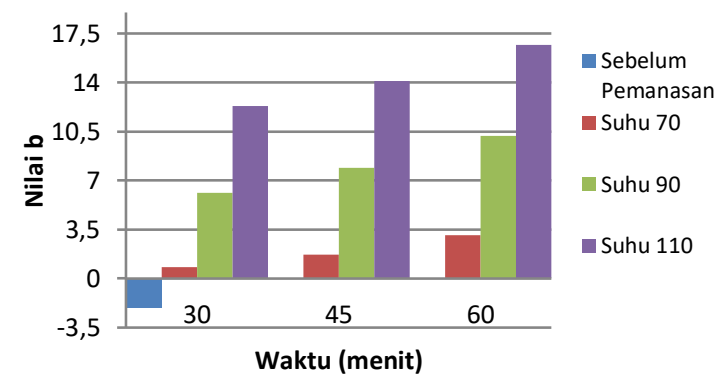

Gambar 10. Grafik Parameter Nilai *b

Pada penelitian ini diperoleh nilai $* b$ untuk suhu $70{ }^{\circ} \mathrm{C}$, suhu $90^{\circ} \mathrm{C}$, dan suhu 110 ${ }^{\circ} \mathrm{C}$. Suhu $70{ }^{\circ} \mathrm{C}$ waktu pemanasan 30 menit 
nilai *b 0.8 , suhu $70{ }^{\circ} \mathrm{C}$ dengan waktu 45 menit diperoleh nilai $*$ b 1.7 , suhu $70{ }^{\circ} \mathrm{C}$ dengan waktu 60 menit diperoleh nilai $*$ b 3.1, suhu $90{ }^{\circ} \mathrm{C}$ waktu 30 menit diperoleh nilai *b 6.1, suhu $90{ }^{\circ} \mathrm{C}$ waktu 45 menit nilai *b yang didapat adalah 7.9, suhu $90{ }^{\circ} \mathrm{C}$ waktu 60 menit diperoleh nilai *b 10.2, suhu $110{ }^{\circ} \mathrm{C}$ dengan waktu pemanasan 30 menit diperoleh nilai $*$ b 12.3 , suhu $110{ }^{\circ} \mathrm{C}$ dengan waktu pemanasan 45 menit diperoleh nilai *b 14.1, dan suhu $110^{\circ} \mathrm{C}$ waktu pemanasan 60 menit nilai *b yang diperoleh adalah 16.7. Dari hasil pengamatan yang diperoleh dapat disimpulkan bahwa semakin tinggi suhu yang digunakan dan semakin lama waktu pemanasan maka nilai *b yang didapat semakin tinggi.Nilai $* b$ mengindikasikan warna kuning dan biru. Warna bahan makanan biasanya diukur dalam unit L, *a, *b yang merupakan standar internasional pengukuran warna, diadopsi oleh CIE (Commission Internationale d'Eclairage). L untuk mendekripsikan warna, 0 untuk gelap dan $\mathrm{L}=100$ untuk terang, dimensi $*_{\mathrm{a}}$ mendeskripsikan jenis warna hijau-merah, dimensi $*$ b untuk jenis warna biru-kuning (Leön, 2005).

\section{Nilai Viskositas}

Viskositas menjadi salah satu sifat fisik yang penting pada bubur kulit buah naga. Pengujian viskositas dilakukan untuk mengetahui tingkat kekentalan bubur kulit buah naga sebagai larutan pada konsentrasi dan suhu tertentu. Dan dapat dilihat pada grafik sebagai berikut:

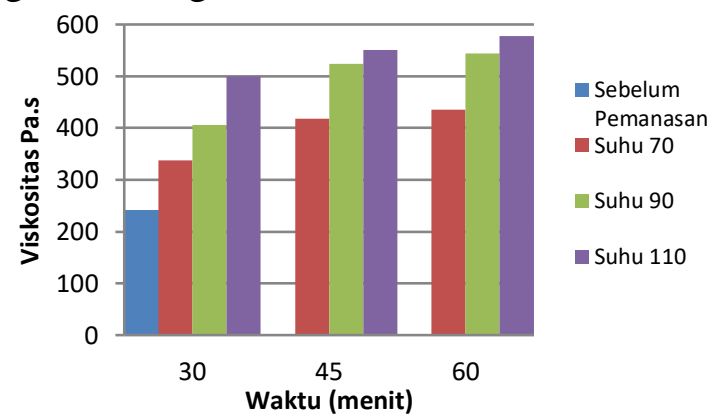

Gambar 11. Grafik Nilai Viskositas bubur kulit buah naga pada Rpm 60

Pada gambar 11 menunjukan nilai viskositas yang didapatkan pada setiap suhu dan lama waktu pemanasan pada $60 \mathrm{Rpm}$.
Dapat dilihat bahwa semakin tinggi suhu yang digunakan dan semakin lama pemanasan maka nilai viskositas yang didapatkan juga semakin tinggi. Dimana suhu $70{ }^{\circ} \mathrm{C}$ waktu 30 menit nilai viskositasnya adalah $241 \mathrm{mPa} . \mathrm{s}$, pada suhu $70{ }^{\circ} \mathrm{C}$ waktu 45 menit nilai viskositasnya adalah $418 \mathrm{mPa}$.s, suhu $70{ }^{\circ} \mathrm{C}$ waktu 60 menit viskositasnya adalah $435 \mathrm{mPa} . \mathrm{s}$, suhu $90{ }^{\circ} \mathrm{C}$ waktu 30 menit nilai viskositasnya adalah $406 \mathrm{mPa} . \mathrm{s}$, suhu $90{ }^{\circ} \mathrm{C}$ waktu 45 menit nilai viskositasnya adalah $524 \mathrm{mPa} . \mathrm{s}$, suhu $90{ }^{\circ} \mathrm{C}$ waktu 60 menit viskositasnya adalah 544 mPa.s. Suhu $110{ }^{\circ} \mathrm{C}$ waktu 30 menit nilai viskositasnya adalah $500 \mathrm{mPa}$.s, suhu $110{ }^{\circ} \mathrm{C}$ waktu 45 menit nilai viskositasnya adalah $551 \mathrm{mPa} . \mathrm{s}$, suhu 110 ${ }^{\circ} \mathrm{C}$ waktu 60 menit viskositasnya adalah 578 mPa.s.

\section{KESIMPULAN}

Berdasarkan penelitian yang telah dilakukan maka dapat disimpulkan bahwa:

1. Laju perubahan suhu bubur kulit buah naga merupakan fungsi linier dari lama pemanasan.

2. Konduktivitas listrik meningkat secara linear untuk suhu $70{ }^{\circ} \mathrm{C}$ dan $90{ }^{\circ} \mathrm{C}$ namun untuk suhu $110{ }^{\circ} \mathrm{C}$ peningkatan konduktivitas listriknya pada saat mencapai suhu $100{ }^{\circ} \mathrm{C}$ cenderung menurun akibat adanya gelembunggelembung udara yang mengganggu aliran listrik dalam bahan.

3. Kadar antosianin sangat dipengaruhi oleh suhu dan lama pemanasan pada kulit buah naga, semakin tinggi suhu dan semakin lama waktu pemanasan maka semakin rendah kadar antosianin yang didapatkan. Nilai kadar antosianin tertinggi diperoleh dengan suhu pemanasan $70{ }^{\circ} \mathrm{C}$ lama waktu pemanasan 30 menit yaitu 12.9 $\mathrm{mg} / \mathrm{L}$ sedangakan nilai yang terendah diperoleh dengan suhu pemanasan $110{ }^{\circ} \mathrm{C}$ dengan lama pemanasan 60 menit yaitu $1.45 \mathrm{mg} / \mathrm{L}$. 


\section{DAFTAR PUSTAKA}

Arifah, Nur. 2016. Studi Konduktivitas Listrik Kentang (Solanum tuberosum L.) Dengan Pemanasan Ohmic. Universitas Hasanuddin : Makassar

Astawan M., dan Kasih AL. 2008. Khasiat warna-warni makanan. Jakarta: Gramedia Pustaka Umum.

Hanum, T. 2000. Ekstraksi dan Stabilitas Zat Pewarna Alam dari Katul Beras Ketan Hitam (Oryza sativa glutinosa). Bul. Teknol. Dan Industri Pangan, Vol. XI, No.1. Jurusan Teknologi Hasil Pertanian Fakultas Pertanian Universitas Lampung. Bandar Lampung.

Hidayah, Tri. 2013. Uji Stabilitas Pigmen Dan Antioksidan Hasil Ekstraksi Zat Warna Alami Dari Kulit Buah Naga (Hylocereus Undatus) Universitas Negeri Semarang : Semarang

Ingrath, Windha., Wahyunanto A.N., dan Rini Y. 2015. Ekstraksi Pigmen Antosianin Dari Kulit Buah Naga Merah (Hylocereus Costaricensis) Sebagai Pewarna Alami Makanan Dengan Menggunakan Microwave (Kajian Waktu Pemanasan Dengan Microwave dan Penambahan Rasio Pelarut Aquades Dan Asam Sitrat). Jurnal Bioproses Komoditas Tropis Vol. 3 No. 3

Leön. 2005. Color Measurement In $L^{*} A * B^{*}$ Units From $R g b$ Digital Images. Publication In Journal Of Food Engineering. Vol. I, Page 1-23.

Mastuti, Endang., Maria, G. N. W., dan Pradito, H. 2013. Ekstraksi Zat Warna Alami Kelopak Bunga Rosella Dengan Pelarut Etanol. Ekuilibrium Vol. 12.No. 2. Halaman : $49-53$

Ruan, R., Ye, P., Chen., dan Doona, C.J. 2001. Thermal Tecnologies in Food Processing. CRC Press, New York.

Sastry, S. K., and Barach. 2002. Ohmic Heating and Moderate Electric Field
(MEF) Processing. Journal of Engineering and Food for The $21^{\text {st }}$ Century (47): 785-791.

Sastry, S.K., and Paniappan, S. 2001. Ohmic heating of liquid particle mixtures. Food technology.

Winarti, Sri., dan Adurrozaq, Firdaus. 2010. Stabilitas Warna Merah Ekstrak Bunga Rosela Untuk Pewarna Makanan Dan Minuman. Jurnal Teknologi Pertanian Vol. 11 No. 2.

Winarti, Sri., Ulya, Sarofa., dan Dhini, Anggrahini. 2008. Ekstraksi Dan Stabilitas Warna Ubi Jalar Ungu (Ipomoea batatas L.,) Sebagai Pewarna Alami . Jurnal Teknik Kimia, Vol.3, No.1. 